DOI: $\underline{10.17805 / g g z .2019 .6 .6}$

\title{
Письмо Натана Филда к Томасу Саттону в контексте театральной полемики раннестюартовской Англии"
}

\author{
В. А. Шипулина, В. С. Макаров
}

Православный Свято-Тихоновский гуманитарный университет, г. Москва

В статье рассмотрен малоизвестный документ театральной полемики в Англии начала XVII в. - письмо актера и драматурга Джона Филда одному из священников иеркви Спасителя и Девы Марии Овери (в настоящее время Саутуоркского собора) Томасу Саттону. Сопоставляя позицию Филда с критикой театра, которую в сохранившихся проповедях вел сам Саттон, а ранее - отеи Филда, известный пуританский проповедник, авторы показывают, что важной частью театральной полемики был спор о месте актера в христианском обществе. Филд настаивает на праве актеров быть одновременно и чадами Церкви, а не работниками кощунственной школь соблазна.

Ключевые слова: Натан Филд; Томас Саттон; Джон Филд; полемика вокруг театра; история английского театра; Англия XVI-XVII вв.

\section{Nathan Field's Letter to Thomas Sutton in the Context of Theatrical Polemic in Early Stuart England}

\author{
V. A. Shipulina, V. S. Makarov
}

St. Tikhon's Orthodox University, Moscow

The article examines a little-known document of theatrical polemic in early 17 th century England - a letter written by actor and playwright John Field to one of the priests at the church of St. Saviour and St. Mary Overie (nowadays Southwark Cathedral), Thomas Sutton. By juxtaposing the position defended by Field and the scathing critique of theatre delivered by Sutton in his sermons, and before him, by John Field, the famous Puritan preacher and father of the actor, the authors show that debates on what place an actor should occupy in Christian society formed an important part of the theatrical polemic. Field firmly insisted that actors

\footnotetext{
* Статья подготовлена в рамках проекта «Генезис литературного текста в эпоху позднего Средневековья и раннего Нового времени: взаимодействие стилей и жанров» при поддержке Фонда развития Православного Свято-Тихоновского гуманитарного университета. The article was prepared within the framework of the project "Genesis of Literary Texts in the Late Middle Ages and Early Modern Period: Interaction of Styles and Genres" supported by PSTGU Development Foundation.
} 
are and should be seen as loyal sons of the Church, rather than those in service of the blasphemous school of temptation.

Keywords: Nathan Field; Thomas Sutton; John Fielde; theatrical polemic; history of English theatre; England in 16th-17th centuries

\section{ВВЕДЕНИЕ}

Дискуссии о театре и его социальной и моральной роли идут уже не первый век. Древняя Церковь боролась с наследием античного театра как порождения язычества. Религиозные споры эпохи Реформации и Контрреформации также не могли обойти эту тему, и в годы правления Елизаветы I Тюдор в Англии обострилась полемика вокруг театральной сферы.

Появление публичных театров в 1570-е гг. практически сразу вызвало к жизни критику этого института как вредного для нравственности ${ }^{1}$. В дальнейшем спор условных «противников» и «защитников» театра, которые на самом деле могли занимать очень разные политические и конфессиональные позиции, становился все более острым. Он имел и свой политический аспект - театр защищали при королевском дворе, в то время как на стороне его критиков было самоуправление многих английских городов, в частности, Лондона. Этот политико-религиозный (в том, например, что касается самоуправления общин) конфликт неизбежно проецировался на театр.

Однако он не был простой калькой противостояния «англикан» и «пуритан». Так, критики театра Стивен Госсон (Stephen Gosson) и Филип Стаббс (Philip Stubbs / Stubbes) высказывались и против «пуританских» настроений, а драматург Энтони Манди (Мандей / Anthony Munday), написав в 1580 г. трактат «Второй и третий трубный глас к тому, чтобы отступить от пьес и театров» ("Second and Third Blast of Retreat from Plays and Theaters"), вскоре снова вернулся к драматургии.

С учетом того, что закончился этот спор закрытием театров, как только двор потерял де-факто контроль над Лондоном в 1642 г., критики и литературоведы последующих эпох легко выстраивали нарратив о непреодолимом различии между «прогрессивными» гуманистами-людьми театра и необразованными «церковниками», огульно критиковавшими его. Как мы видели на примере трактата Джона Нортбрука (Макаров, Колесник, 2019: 94-96), критики театра могли, например, делать исключение для школьных и университетских постановок и почти всегда, так же как и его сторонники, аргументировали свою позицию, исходя из во многом схожего набора источников (от-

\footnotetext{
${ }^{1}$ Об одном из первых критиков театра Джоне Нортбруке (John Northbrooke) см. подробнее: Колесник, Макаров, 2019.
} 
цы Церкви, античные авторы, которых обе стороны спора изучали в университете).

\section{НАТАН ФИЛД - АКТЕР И ДРАМАТУРГ}

Хорошим примером подобной «поляризации» мнения критиков стал актер и драматург Натан Филд (Nathan Field, 1587-1619/1620), и прежде всего потому, что его собственная судьба, на первый взгляд, хорошо укладывается в схему «поляризации». Будущий актер был сыном известнейшего лондонского проповедника Джона Филда (John Field / Fielde; 1544/1545-1588), неоднократно преследовавшегося за радикальные взгляды. Никто из сыновей Филда не пошел по отцовскому пути: Теофилус стал епископом англиканской Церкви, Натаниэль - печатником, а самый младший, Натан, с ранней юности оказался связан с театром. В биографиях Филда часто повторяется мотив «иронии судьбы» - так, Э. Ферхассельт полагает: «Характерно, что это письмо написал сын пуританина Джона Филда, известного своими нападками на театр, и брат епископа Теофилуса» (Verhasselt, 1946: 507; здесь и далее перевод наш. - $B . W ., B . M.)^{2}$. Возник некий потенциал для того, чтобы видеть в Филде «протестную фигуру», «борца с ортодоксией». Участник труппы Детей королевы (Children of the Queen's Revels), где ставились радикальные пьесы Дж. Марстона, Б. Джонсона и других авторов начала XVII в., Филд прожил недолгую жизнь, но успел стать пайщиком Слуг короля (уже после смерти У. Шекспира), и если верить слуху, записанному послом в Голландии Уильямом Трамбуллом (William Trumbull), Энн, графиня Аргайлская (Anne, Countess of Argyll) тайно родила от «актера Нат. Филда» (см. подробнее: Brinkley, 1973: 42). В пользу этой версии о талантливом актере - защитнике театра говорит и совершенно не доказанное, но очень популярное представление, что Филду перешел пай Шекспира в труппе Слуг короля.

Действительно, Филд стал пайщиком компании не позднее 28 апреля 1619 г. (Williams, 2004: Электронный ресурс), а вступил в нее в качестве нанятого актера, скорее всего, в конце 1616 г. Вместе с двумя своими товарищами по детской труппе, Уильямом Остлером (William Ostler) и Джоном Андервудом (John Underwood), Филд упомянут в шекспировском Первом фолио как один из основных актеров, игравших в шекспировских постановках. Однако его карьера в компании оказалась очень короткой - 2 августа 1620 г. его сестра Доркас ${ }^{3}$ уже вступала в права наследства покойного брата.

\footnotetext{
2 "It is typical that this paper was written by the son of John Field the Puritan, who himself attacked théâtres, and the brother of Theophilus, the bishop".

${ }^{3}$ Греческий вариант арамейского имени Тавифа, основанный на переводе смысла имени — «серна».
} 
Как актера Филда часто сравнивали с Э. Эллином и Р. Бербеджем. Показателен, например, фрагмент из анонимной пьесы 1635 г. «Триумвират остроумия, или философ» (“Wit's Triumvirate, or The Philosopher"): доктор Клистер застает своего пациента сэра Купидона Фэнтзи за сочинением стихов, от которого доктор его лечит. Купидон кричит и размахивает руками, сочиняя стихи, чем и вызван вопрос доктора:

Cly[ster]: What[,] so lowd and acting as if Burbedge's soule had newly reviv'd Hamlett, \& Jeronimo againe, or Allen, Tamberlayne?

$\mathrm{Ph}[$ antsy]: Nay, Sir, rather Feild, in Love Lyes a bleeding.

(IV, 4; цит. по: Williams, 1992: 33)

Как небезосновательно полагает М. Уильямс, автор комедии, а возможно, и сам Филд видят определенную разницу в актерском стиле Бербеджа и Эллина, с одной стороны, как актеров старшего поколения, и Филда как «нового Бербеджа». Несмотря на то, что карьера его была все же короче, чем у Эллина или Бербеджа (менее 20 лет против минимум 25 - у первого и почти 40 - у второго), Филд успел оставить о себе глубокую память. Как драматург, Филд также не наследник Шекспира - в начале карьеры он близок Б. Джонсону, а затем также Ф. Мессинджеру и Дж. Флетчеру.

Наконец, история прихода Филда в театр также напоминает скорее криминальную хронику, чем историю подросткового бунта. В 1600 г. Звездная палата начала разбирать жалобу, которую джентльмен по имени Генри Клифтон (Henry Clifton) подал на органиста Натаниэля Джайлса (Nathaniel Giles) и труппу Детей королевской капеллы (Children of the Chapel Royal). По мнению Клифтона, они похитили его сына Томаса и заставили его стать хористом и актером. Компания действовала, как ни странно в это поверить, в рамках законных полномочий, но Клифтон использовал связи при дворе, а также огласил список других похищенных детей, среди которых оказался и ученик грамматической школы при соборе св. Павла Натан Филд (см.: Brinkley, 1973: 18-20) ${ }^{4}$. Бринкли видит здесь пример произвола: у сироты Филда заступников не оказалось; так и пришлось ему стать актером. Вероятно, это тоже натяжка: Филд, как следует из посмертных сравнений с Бербеджем и Эллином, обладал явным актерским талантом и, скорее всего, сам быстро это понял.

Итак, несмотря на то, что о жизни Филда известно мало, а в некоторых случаях его еще и путали с братом-печатником Натаниэлем, биографические

\footnotetext{
${ }^{4}$ Стоит отметить, что Клифтон-старший не возражал, чтобы его сын был хористом, но был категорически против актерства.
} 
мифы пытались «поляризировать» его. М. Уильямс высмеивает, в частности, представление Э. К. Чемберса и У. Пири ${ }^{5}$ о Филде как богемном актере, «лишенном корней» и «семейных добродетелей», да еще и недоучившемся (Williams, 1992: 25-26) ${ }^{6}$. Такой «мифобиографизм» не развился в полной мере, как это произошло с К. Марло или У. Шекспиром, лишь потому, что Филд оказался менее известен культуре последующих столетий.

Его письмо в защиту театра, которое сохранилось среди государственных архивных документов, касающихся внутренних дел (State Papers Domestic), было найдено лишь в XIX в. и впервые опубликовано Дж. Хэлливеллом-Филипсом (Field, 1874). На первый взгляд, оно дает немало оснований для поляризирующей мифобиографии: Филд выступает против известного лондонского проповедника, делает это публично, пусть и в рукописной форме, жестко критикуя проповедь Томаса Саттона в Саутуоркской церкви (также известном как церковь Спасителя и Девы Марии Овери, т. е. расположенная на противоположном от Лондона берегу Темзы).

К сожалению, провенанс и палеография документа остаются неизученными. Он находится в архиве за 1616 год, и на полях поставлена соответствующая дата, но все остальное неясно - чьей рукой написан текст (начиная с Хэлливелла, исследователи полагают, что писца) и как и зачем он попал в архив. Но прежде чем перейти к анализу логики текста, обратимся к тому, что о театре говорили и писали Филд-старший и Томас Саттон, чья проповедь в Саутуоркской церкви так возмутила Натана Филда.

Эти два автора, несмотря на их общее неприятие театра, стояли на совершенно разных позициях. Получив степень бакалавра в Оксфорде, лондонец Джон Филд вернулся в родной город, где стал одним из священников церкви Девы Марии в Олдермэри и выступал за преобразование епископской иерархии в объединение синодов, состоящих из свободных общин. Его не изгоняли из города, но неоднократно запрещали проповедовать ${ }^{7}$. Вместе с Томасом Уилкоксом (Thomas Wilcox) Филд написал и издал «Предостережение парламенту» (“An Admonition to the Parliament”) — важный источник по ранней истории церковного радикализма в Англии.

\section{«ПРЕДОСТЕРЕЖЕНИЕ ПАРЛАМЕНТУ》}

Для Дж. Филда и Т. Уилкокса критика театра была частью большого религиозно-политического проекта — освобождения Церкви Христовой от

\footnotetext{
5 "I find it equally hard to accept the view of Field put forward by Peery" (Williams, 1992: 26).

6 "His unsettled life had cut him off from any deep roots such as love of country, the home or conventional domestic virtues; it had not given him the schooling of a man of letters" (Peery, 1950: 13).

${ }^{7}$ О Филде см. подробнее: Collinson, 1961.
} 
католического наследия, и театру прежде всего уподоблялся «папизм». Так, католическое богослужение несет не наставление в вере, а смущение ее из-за того, что псалмы читают суетно, будто играют в теннис: "In all theyr order of seruice there is no edification... but confusion, they tosse the Psalmes in most places like tennice balles" (Fielde et al., 1572: Sig. В4v). В храме свободно ходят и разговаривают во время мессы, да и священник служит «галопом», как будто опаздывает в другой приход или на какие-то игрища - языческий хоровод, травлю быков или медведей, скачки обезьяны в седле или театральную интерлюдию: “The people some standing, some walking, some talking, some reading, some praying by themselues... He againe posteth it ouer, as fast as he can galloppe. For eyther he hath two places to serue, or else there are some games to be playde in the afternoone, as... heathnishe dauncing for the ring, a beare or a bull to be baited, or else Iacke an apes to ride on horssebacke, or an enterlude to be plaide" (ibid.). Завершает этот фрагмент Филд пугающим образом интерлюдии, которую играют за нежеланием искать другое место прямо в церкви: "...if no place else can be gotten, this enterlude must be playde in the church, \&c." (ibid.).

Театр для Филда важен прежде всего как образ того, во что уже превратилась католическая Церковь и может превратиться англиканская. Он не столько призывает не ходить на эти нечестивые зрелища (это его аудитории и так понятно), сколько выстраивает антииерархию: от дьявола прежде всего церковное нестроение, а потом уже театры. Пустое, без истинной веры, чтение Слова - такое же зло (и даже большее), чем произнесение слов со сцены, а актеры для него почти что неграмотны: "For bare reading of the word and single seruice saying, is bare-feeding, yea it is as euil as playing vpon a stage, \& worse too. For players yet learne theyr partes wythout boke, and these, a many of them can scarsely read win boke" (ibid.: Sig.B1r). «Уснувшие стражники», «слепые поводыри», «соль, потерявшая силу», «нерадивые работники в винограднике» - о ком здесь речь - актерах или потерявших веру христианах? Трудно сказать, вероятно, и о тех, и о других.

\section{«ВРАЗУМЛЕНИЕ БОЖИЕ...»}

Другой текст Филда, где зрелища для него - уже не просто метафора маловерия - это «Вразумление Божие...» (“A Godly Exhortation...”; Fielde, 1583). Напечатанный, в отличие от «Предостережения парламенту», официально, этот трактат-проповедь был написан после того, как в заведении для травли медведей рухнула галерея, похоронив под собой зрителей, пришедших в «Парижский сад» (Parris Garden) в воскресенье. Все они — и погибшие, и спасшиеся - согрешили против заповеди «Чти день субботний». В городе, жители которого уже почти тысячу лет христиане, Филда ужасает то, 
что театры полны, и даже на улице людей больше, чем в церкви. Филд допускает, что травля медведей может быть дозволенным развлечением - но не в воскресенье, иначе иерархия нарушается.

Подробный рассказ с упоминанием имен и занятий жертв Филд завершает призывом к городскому самоуправлению Лондона запретить представления хотя бы по воскресеньям (в частности, «языческие интерлюдии и пьесы» _ "...that vppon Sabaoth dayes these Heathnish Enterludes and Plaies are banished, so it will please them to followe the matter still, that they may be vtterlye rid and taken away. For surely it is to be feared, besides the distruction both of bodye and soule, that many are brought vnto, by frequenting the Theater, the Curtin and such like, ye one day those places wyl likewise bée cast downe by God himself" (ibid.: C5r-C5v). Это только первый шаг, после которого можно их полностью запретить - иначе Господь Сам разрушит дом греха, и «Театр» с «Куртиной» постарадают так же, как «Парижский сад» — и эта катастрофа будет символом погибели тела и души грешника.

Несомненно, взгляд отца на театр нашел бы у сына мало сочувствия, но в такой почти что предапокалиптической картине театр не может быть главным врагом. Его место в «альтернативной иерархии» на самой поверхности, и актеров и зрителей Филд обличает примерно одинаково.

\section{ПРОПОВЕДИ ТОМАСА САТТОНА}

Точно не известно, какая из проповедей Томаса Саттона (1585-1623) подтолкнула Филда к ответу. Саттон - почти ровесник актера и драматурга, к 1616 г. - магистр искусств и один из священников церкви в Саутуорке. Как известно, в приходе будущего Саутуоркского собора состояло немало актеров и людей театра, которых Саттон, очевидно, и избрал своей мишенью. В отличие от Филда-старшего Саттон не склонен к радикализму, он англиканин, хотя против иезуитов и католиков выступает не менее яростно. Родом из бедной семьи с севера Англии, в Лондоне он, вероятно, чувствовал себя не совсем своим и, собрав в Саутуорке средства на то, чтобы достроить школу в приходе, отправился на родину, но на обратном пути погиб при кораблекрушении. Вероятно, ранняя смерть помешала собрать и издать его проповеди. Из сохранившегося и изданного театр упоминается в серии из двух проповедей, прочитанных с т. н. «Креста св. Павла» у одноименного собора (чего удостаивались далеко не все проповедники).

Из ответа Филда ясно, что в Сауторкской церкви Саттон обличал в нечестии актеров, чуть ли не указывая на каждого перстом. Это, конечно, плохо вписывается в проповедническую традицию, особенно учитывая, что актеры составляли небольшую, но важную часть прихода. Цель этой атаки не очень понятна. Изгнать актеров из прихода было нереально, учитывая, что 
Саутуорк не подчинялся властям лондонского Сити. Утверждая, что их ремесло в принципе греховно, Саттон ставил под вопрос пребывание актеров в церкви и, возможно, входил в конфликт с другими священниками (как древний и важный храм, церковь управлялась коллегиально).

Проповеди Саттона у креста св. Павла роднит с текстами Филда призыв к городским властям «рубить под корень грех в городе» (“Strike at the root of sinne in the City"; Sutton, 1616: 88), использование театра как метафоры греховного пространства (с которым сравнивается двор - "If you chance to come neere the court, you would thinke you were entred upon a stage" (ibid.: 154).

Для Саттона пьесы, с одной стороны, особенно вредны для молодых ("the general and noble Buddes of this Land"; ibid.: 36), а с другой, они кладут пятно на честь всего города ("your prophane and obscoene stage plaies do proue the inexpiable stayne and dishonour of this famous City"; ibid.). Продолжая метафору «юных побегов», Саттон видит в театрах червей, губящих и оскопляющих будущие цветы: “...the noysome wormes that canker, and blast al hope of grace and goodnes in the blossomes, that they do so weaken and emasculate all the seeds of holinesse" (ibid.: 38). Особенно Саттона раздражает «хитрый и колдовской обман» (“а slie and bewitching insinuation”): притворяясь законным развлечением, они разжигают в зрителях худшие страсти. Из концовки фрагмента, кажется, становится ясно, что Саттон (обращаясь в этой части к судьям и юристам) особенно переживает за студенческие представления в лондонских правовых школах: “...whereas they are planted in these nurceries of the Law... they licentiously dissolve into vngodlie and wanton pleasures" (ibid.). Ha такие спектакли посторонних не пускали, и тот же Дж. Нортбрук несколькими десятилетиями ранее признавал их пользу. Но Саттон тут же перескакивает на публичные театры, которые содержат людей порочных (очевидно, актеров: “...they will not cease to flock into such wanton Theaters, and there to spend their goods to no other purpose but to set their own lusts on fire, to vphold Schooles of lewdnesse and of sin, to maintain men of corrupt life and dissolute behauiour in a calling in no way warranted from God?" (ibid.: 38-39). Оба типа представлений работают одинаково: они притворяются законными развлечениями, но на самом деле подменяют ("licentiously dissolue into vngodly and wanton pleasures") стремление к общему благу ("the continuance of the glorie, and happinesse of this Kingdome”) (ibid.: 37) на индивидуальные наслаждения. «Черви» театра, поедая отдельные цветы, уничтожают постепенно весь сад. Это довольно типичная полемическая логика для своего времени. Обычно она направлена против ростовщиков, укрывателей краденого, спекулянтов зерном - словом, всех тех, кто свое личное благо ставит выше общего. На голову актеров Саттон призывает кару небесную, «если слово проповедника 
не сведет их с пути греховной профессии» (“...if they refuse to be reclaimed from this trade of sinne by the mouth of the Preacher"; ibid.: 39).

В посмертном сборнике проповедей на одиннадцатую главу Послания к Римлянам (Sutton, 1632) актеры мимоходом появляются среди тех, кто своим занятием бесчестит Господа - вместе с ростовщиками, содержателями игорных домов и драматургами: “Ву this (I hope) some will learne at last to give over their calling, whereby they bring not honour, but dishonour unto God: Those that live upon usurie, by dicing houses, by penning and acting of playes, let them all remember this, mine heart trembles to thinke, what calling these men have" (ibid.: 477).

Как видим, Саттон в нескольких текстах (скорее всего, и в проповеди в Саутуоркской церкви тоже) атакует актеров как нарушителей Божественного закона в том виде, как он проявляется в жизни общества. Рядом с ними ростовщики и другие губители социального организма, а не католики и сам отец лжи. Для Саттона актеры гораздо реальнее, чем для Филда, и, опираясь на «моральные паники» раннестюартовского общества, он призывает их отказаться от своего ремесла (вряд ли при этом в руках одного из младших священников капитула была какая-либо прерогатива накладывать на них прещения).

\section{ОТВЕТ Н. ФИЛДА Т. САТТОНУ}

В этом контексте следует рассматривать и ответ Н. Филда. Нельзя не согласиться с исследователями, что он начисто переигрывает Т. Саттона на этом поле. В сущности, перед нами не совсем и не только театральная полемика. Филд сосредоточен на одном аргументе Саттона — что актерское дело и театр неискупимо греховны по самой своей природе. Вырвать актеров из связки с ростовщиками - уже означает создать для них модель легитимного присутствия в городе и приходе.

Саттон отличался от других критиков театра тем, что решил обличить актеров открыто. Аналогично и ответ Филда создает впечатление прямой полемики, хотя мы и не знаем, дошло ли послание до адресата. Актер и драматург практически полностью проигнорировал частные аспекты полемики, сосредоточившись на главном - актеры и люди театра не должны быть исключены из церковного общения, их вера вполне искренна, а профессия совместима с христианством. Филд начинает письмо исповеданием веры, которое отчасти напоминает первые абзацы завещаний.

Называя свое слово в защиту театра «речью», Филд конструирует ситуацию публичного выступления в защиту прав группы, которую представляет. Несправедливое обвинение зажгло в его душе огонь прежде всего потому, что Саттон обличал актеров публично и страстно: “The fire is kindled and I 
must speak; and the rather because you have not spared in the extraordinary violence of your passion particularly to point at me and some other of my quality, and directly to our faces in the public assembly to pronounce us damned, as though you meant to send us alive to hell in the sight of many witnesses" (Field, 2004: 276).

Оба этих качества проповеди Саттона для Филда ошибочны. «Отправление актеров в ад в присутствии множества свидетелей» - большая пастырская ошибка, которую Филд противопоставляет любви Христа к овцам Его стада и сравнивает с поведением кормилицы, которая отравляет ребенка ядом или, в крайнем случае, пастуха, который, ленясь сам загонять овец, посылает за ними злую собаку (ibid.). Эта косная жесткость соблазняет актеров ответить злобой (choler) в сердце, что удаляет их от спасения, а не приближает к нему.

Остается не отмеченным исследователями тот факт, что Филд, отвечая Саттону, ставит священника в некоторую зависимость от прихода: проповедник принимает (разумеется, не напрямую) десятину от тех, кого он считает обреченными аду, но ничего не делает для них. Такое деяние Филд называет «немилосердным» (“...uncharitable dealing with your poor parishioners, whose purses participate in your contribution and whose labor you are contented to eat, howsoever you despise the man that gains it or the ways he gets it..."; ibid.). Вoзможно, в этом усмотрели что-то схожее с радикальными «пуританскими» требованиями и потому сохранили текст письма.

Филд заявляет, что сеять раздоры он отнюдь не собирается - но, выступая от своего имени и от имени своей части прихода, протестует против произвола проповедника, отказывающего им даже в праве быть христианами: "...I desire you to conceive that I enter not the list of contention, but only take hold of the horns of the altar in mine own defense..." (ibid.). Интересен ветхозаветный образ «рогов алтаря» (ср., например, Исход 27, Левит 34) - в метафоре Филда он хватается за них из отчаяния, не желая быть выброшенным наружу. Из Ветхого Завета известно, что за рога жертвенника подобным образом хватались обвиненные в преступлении, желая получить право убежища от преследования (Адония в 3 Цар. 1:50).

Современные исследователи нередко говорят об «актерской» поэтике Филда, который в разных жанрах легко приспосабливается к жанровым требованиям. Так, С. Орман в своей недавней диссертации связывает «страстное послание» Филда с теми образцами, которые он изучал в грамматической школе (Orman, 2014: 182) и называет письмо Саттону и другие эпистолярные тексты Филда «перформативными» (ibid.: 186, 188). С этим трудно спорить, но очевидно, что перед нами все же не театральная перформативность, а скорее попытка обдуманной и сдержанной «прямой речи» в стиле античной парресии. 
Действительно, значительную часть письма занимает объяснение, почему Саттон совершил ошибку, поддавшись собственной эмоции. Как указывает тот же Орман, с одной стороны, эта логика уходит корнями в гуморальную медицину: «излишняя страсть» проповедника свидетельствует о гуморальном дисбалансе: “...Field lambasts Sutton for the preacher's own 'extravagant and unnecessary passions', suggesting that the preacher has failed to regulate his own bodily excesses..." (ibid.: 187).

С другой стороны, что намного более важно, Филд проводит грань между церковью и театром. Эту проблему исследовала автор первого содержательного исследования этого текста П. МакКи. Церковь - дом абсолютной Истины, где всякое уклонение от нее ведет ко лжи, но и театр - не царство абсолютной лжи и ее отца. Принимая различие между реальностью и тем, что мы видим на сцене, полагает МакКи, мы тем самым обязуемся принимать и моральную правду театра и его способность обличать грех (McKee, 2016: 278-279). Театр в интерпретации Филда, полагает исследовательница, не вреден для души именно потому, что мы соглашаемся отличать его от жизни (ibid.: 285). Тогда актер - это не способ существования, а ремесло. Случаи обличения греха в театре связаны не столько с индивидуальным актерским талантом (вспомним «Мышеловку» в шекспировском «Гамлете» или приводимый Т. Хейвудом в «Апологии актеров» пример женщинымужеубийцы, которая случайно пришла на спектакль, где способ убийства был повторен на сцене), сколько с силой театра как такового.

От актера - и от проповедника тоже, по мнению Ормана и МакКи, требуется не исключительный дар, а точное следование своему предназначению и владение своими эмоциями. Саттон поддался своему отвращению к актерам - и нарушил мир прихода. Ожесточившиеся в сердце, актеры могут не захотеть больше слушать и благих наставлений, против которых Филд, разумеется, не возражает. Говоря о «соприкосновении с реальным» (термин С. Гринблатта - "the touch of the real"; Greenblatt, 1997), Макки пытается вообразить, как театр и церковь могли сосуществовать в нескольких сотнях метров друг от друга, так что пьесу в открытом театре, возможно, перебивал колокольный звон 8 .

Наконец, аргументы Филда в защиту театра немногочисленны и тесно связаны с заявленной им целью указать проповеднику на его ошибку. Ни в Ветхом, ни в Новом Завете актерское ремесло не проклято. Тот факт, что оно в Библии вообще не упомянуто, нельзя расценивать как неодобрение, ведь в Ветхом Завете не упомянуты, например, и кузнецы: "Why, sir, there was a time

\footnotetext{
8 Эта последняя деталь, на наш взгляд, маловероятна - представления проходили после обеда, когда утренняя служба давно завершилась, а до вечерней еще оставалось время.
} 
there was no smith in Israel. Are all smiths therefore damned? A sinful conclusion!” (Field, 2004: 277). Филд полностью обходит ключевую проблему полемики вокруг театра - обличение античных зрелищ Отцами Церкви. Он лишь ссылается на изгнание актеров из Рима Тиберием, противопоставляя его современным ему христианским монархам, которые театру, наоборот, покровительствуют. Иаков Стюарт - нынешний Цезарь, Давид и Иисус Навин (последний образ довольно странен, учитывая демонстративно миролюбивую политику Иакова) - также не считает театр делом зазорным (“...holds it no execrable matter to tolerate them..."; ibid.). Тем самым публичная речь против актеров, тем более с кафедры проповедника, представлена как дело неблагое во многих смыслах: она не только сеет раздор в приходе и отвращает актеров от Церкви и спасения, но и потенциально провоцирует смуту во всем обществе.

В статье о Филде и его поэтике в связи с концепцией детства Э. Лэм сталкивает несколько уровней «отцовства» в творческой биографии Филда:

- его отца-проповедника, от чьего наследия он якобы отказывается ("...he deliberately refutes the anti-theatrical background of his biological family, particularly his father, John Field...”; Lamb, 2009: 126);

- драматургов и театральных антрепренеров, чьим сыном он себя признает (ibid.: 127);

- самого театра как такового.

На наш взгляд, такое разделение излишне ригористично. Филду незачем было отказываться от всего отцовского наследия: он обращается к Саттону в стиле, местами весьма напоминающем «Предостережение парламенту». Для актера детской труппы, к тому же сироты, называть «отцами» старших в ней достаточно очевидно, особенно если о чем-то письменно просить. Наконец, все это не отвергает возможности для Филда быть прежде всего сыном Церкви и возвышать голос в свою защиту при попытках отрицать это сыновство.

\section{ЗАКЛЮЧЕНИЕ}

Как и автор «Апологии актеров», сын священника Т. Хейвуд, Н. Филд выстраивает систему аргументов, в которой актер и драматург может быть христианином. В его письме к Т. Саттону церковь и театр существуют в одном мире. Театр не покушается на главенство Церкви и в ее мистической, и в социальной роли, а актеру находится равное место среди прихожан. 


\section{СПИСОК ЛИТЕРАТУРЫ}

Колесник, В. А., Макаров, В. С. (2019) Джон Нортбрук. Трактат, в котором игра в кости, танцы, суетные пьесы и интерлюдии, и другое праздное времяпрепровождение, обычное для дня субботнего, опровергаются силой слова Божиего и древних авторов // Вестник ПСТГУ. Серия III: Филология. Вып. 58. C. 91-110. DOI: 10.15382/sturIII201958.91-110

Brinkley, R. F. (1973) Nathan Field: The actor-playwright. [Hamden, CT] : Archon Books. 154 p. (Yale studies in English, 77).

Collinson, P. (1961) John Field and Elizabethan puritanism // Elizabethan government and society: Essays presented to Sir John Neale / ed. by S. T. Bindoff, T. J. Hurstfield, C. H. Williams. L. : Athlone Press. x, 423 p. P. 127-162.

[Field, N.] (1874) Feild the players letter to Mr Sutton, preacher att St. Mary Overs "The Remonstrance of Nathan Field", addressed to the Rev. Mr. Sutton, Preacher at St. Mary Overy's, Southwark, 1616, against his Denunciations of the Stage... // Illustrations of the life of Shakespeare, in a discursive series of essays on a variety of subjects connected with the personal and literary history of the great dramatist. Pt. 1 / ed. by J. O. Halliwell-Phillipps. L. : Longmans, Green and Co. viii, 128 p. P. $115-117$.

Field, N. (2004) Letter to Revd. Mr. Sutton (1616) // Shakespeare's theater: A sourcebook / ed. by T. Pollard. Malden, MA : Blackwell Publishers. xxxiv, 352 p. P. 274-278.

Fielde, J. (1583) A godly exhortation, by occasion of the late iudgement of God, shewed at Parris-garden, the thirteenth day of Ianvaris: where were assembled by estimation; aboue a thousand persons, whereof some were slaine; $\&$ of that number, at the least, as is crediblie reported, the thirde person maimed and hurt. Giuen to all estates for their instruction, concerning the keeping of the Sabbath Day. L. : Printed by Robert Walde-Graut, dwelling without Temple-barre, and Henry Carre in Paules Churchyard. [44] p.

Fielde, J. et al. (1572) An admonition to the Parliament / J. Fielde, R. Gwalther, T. de Bèze, T. W. [T. Wilcox]. S.l. (Hemel Hempstead?) : Printed by J. Stroud.

Greenblatt, S. (1997) The touch of the real // Representations. No. 59, special issue: The fate of "culture": Geertz and beyond. P. 14-29. DOI: $10.2307 / 2928812$

Lamb, E. (2009) Remembering childhood: Nathan Field's theatrical career // Lamb E. Performing childhood in the early modern theatre: The children's playing companies (1599-1613). Basingstoke ; N. Y. : Palgrave Macmillan. xii, 189 p. P. $118-142$. 
McKee, P. J. (2016) Scorning the image of virtue: The player Nathan Field's letter to the Reverend Thomas Sutton, 1616 // Religion and Arts. Vol. 20. Issue 3. P. 267-289. DOI: 10.1163/15685292-02003001

Orman, S. (2014) Nathan Field's theatre of excess: Youth culture and bodily excess on the early modern stage (1600-1613) : Thesis submitted for the degree of Doctor of Philosophy. Canterbury : Canterbury Christ Church University. 296 p.

Peery, W. (1950) General introduction // The plays of Nathan Field / ed. from original quartos with introductions and notes by W. Peery. Austin : The University of Texas Press. x, 346 p. P. 3-54.

Sutton, T. (1616) Englands first and second summons: Two sermons preached at Paules Crosse, the one the third of Ianuarie 1612; the other the fifth of Februarie, 1615. By Thomas Sutton Batchelour of Diuinitie, then fellow of Queenes Colledge in Oxford, and now preacher at Saint Mary Oueries in Southwarke. L. : Printed by Nicholas Okes for Matthevv Lavv, and are to be sold at his shop in Pauls Church-yard at the signe of the Fox. [10], 249, [1] p.

Sutton, T. (1632) Lectures vpon the eleventh chapter to the Romans. Preached by that learned and godly divine of famous memorie, Dr. Sutton, in St. Marie Overies in Southwarke. Published for the good of all Gods Church generally, and especially of those that were then his hearers. L. : Printed by I[ohn] $\mathrm{H}$ [aviland] for Nicolas Bourne, and are to be sold at his shop, at the south entrance of the Royall Exchange. [28], 478, [16] p.

Verhasselt, E. (1946) A biography of Nathan Field, dramatist and actor // Revue belge de philologie et d'histoire. T. 25, fasc. 3-4. P. 485-508.

Williams, M. E. (1992) "A play is not so ydle a thing": The dramatic output and the theatre-craft of Nathan Field : A thesis submitted to the Faculty of Arts of the University of Birmingham for the degree of Doctor of Philosophy. Shakespeare Institute, University of Birmingham, May. [12], $454 \mathrm{p}$.

Williams, M. E. (2004) Field, Nathan (bap. 1587, d. 1619/20), actor and playwright [Электронный pecypc] // Oxford Dictionary of National Biography. URL: https://www.oxforddnb.com/view/10.1093/ref:odnb/9780198614128.001.00 01/odnb-9780198614128-e-9391 [архивировано в WaybackMachine] (дата обращения: 22.11.2019). DOI: $10.1093 /$ ref:odnb/9391

Дата поступления: 15.12.2019 2.

\section{REFERENCES}

Kolesnik, V. A. and Makarov, V. S. (2019) Dzhon Nortbruk. Traktat, v kotorom igra $\mathrm{v}$ kosti, tantsy, suetnye p'esy i interliudii, i drugoe prazdnoe vremiapreprovozhdenie, obychnoe dlia dnia subbotnego, oprovergaiutsia siloi slova Bozhiego i drevnikh avtorov [John Northbrooke. A treatise wherein dicing, 
dauncing, vaine playes or enterluds with other idle pastimes etc. commonly vsed on the sabboth day, are reproued by the authoritie of the word of God and auntient writers]. Vestnik PSTGU. Seriia III: Filologiia, issue 58, pp. 91-110. (In Russ.). DOI: $10.15382 /$ sturIII201958.91-110

Brinkley, R. F. (1973) Nathan Field: The actor-playwright. [Hamden, CT] : Archon Books. 154 p. (Yale studies in English, 77).

Collinson, P. (1961) John Field and Elizabethan puritanism. In: Elizabethan government and society: Essays presented to Sir John Neale / ed. by S. T. Bindoff, T. J. Hurstfield and C. H. Williams. London : Athlone Press. x, 423 p. Pp. $127-$ 162.

[Field, N.] (1874) Feild the players letter to Mr Sutton, preacher att St. Mary Overs "The Remonstrance of Nathan Field", addressed to the Rev. Mr. Sutton, Preacher at St. Mary Overy's, Southwark, 1616, against his Denunciations of the Stage... In: Illustrations of the life of Shakespeare, in a discursive series of essays on a variety of subjects connected with the personal and literary history of the great dramatist. Pt. 1 / ed. by J. O. Halliwell-Phillipps. London : Longmans, Green and Co. viii, 128 p. Pp. 115-117.

Field, N. (2004) Letter to Revd. Mr. Sutton (1616). In: Shakespeare's theater: A sourcebook / ed. by T. Pollard. Malden, MA : Blackwell Publishers. xxxiv, 352 p. Pp. 274-278.

Fielde, J. (1583) A godly exhortation, by occasion of the late iudgement of God, shewed at Parris-garden, the thirteenth day of Ianvaris: where were assembled by estimation; aboue a thousand persons, whereof some were slaine; \& of that number, at the least, as is crediblie reported, the thirde person maimed and hurt. Giuen to all estates for their instruction, concerning the keeping of the Sabbath Day. London : Printed by Robert Walde-Graut, dwelling without Templebarre, and Henry Carre in Paules Churchyard. [44] p.

Fielde, J. et al. (1572) An admonition to the Parliament / J. Fielde, R. Gwalther, T. de Bèze and T. W. [T. Wilcox]. S.l. (Hemel Hempstead?) : Printed by J. Stroud.

Greenblatt, S. (1997) The touch of the real. Representations, no. 59, special issue: The fate of "culture": Geertz and beyond, pp. 14-29. DOI: 10.2307/2928812

Lamb, E. (2009) Remembering childhood: Nathan Field's theatrical career. In: Lamb, E. Performing childhood in the early modern theatre: The children's playing companies (1599-1613). Basingstoke; New York : Palgrave Macmillan. xii, 189 p. Pp. $118-142$.

McKee, P. J. (2016) Scorning the image of virtue: The player Nathan Field's letter to the Reverend Thomas Sutton, 1616. Religion and Arts, vol. 20, issue 3, pp. 267-289. DOI: $10.1163 / 15685292-02003001$ 
Orman, S. (2014) Nathan Field's theatre of excess: Youth culture and bodily excess on the early modern stage (1600-1613): Thesis submitted for the degree of Doctor of Philosophy. Canterbury : Canterbury Christ Church University. 296 p.

Peery, W. (1950) General introduction. In: The plays of Nathan Field / ed. from original quartos with introductions and notes by W. Peery. Austin : The University of Texas Press. x, 346 p. Pp. 3-54.

Sutton, T. (1616) Englands first and second summons: Two sermons preached at Paules Crosse, the one the third of Ianuarie 1612; the other the fifth of Februarie, 1615. By Thomas Sutton Batchelour of Diuinitie, then fellow of Queenes Colledge in Oxford, and now preacher at Saint Mary Oueries in Southwarke. London : Printed by Nicholas Okes for Matthevv Lavv, and are to be sold at his shop in Pauls Church-yard at the signe of the Fox. [10], 249, [1] p.

Sutton, T. (1632) Lectures vpon the eleventh chapter to the Romans. Preached by that learned and godly divine of famous memorie, Dr. Sutton, in St. Marie Overies in Southwarke. Published for the good of all Gods Church general$l y$, and especially of those that were then his hearers. London : Printed by I[ohn] $\mathrm{H}$ [aviland] for Nicolas Bourne, and are to be sold at his shop, at the south entrance of the Royall Exchange. [28], 478, [16] p.

Verhasselt, E. (1946) A biography of Nathan Field, dramatist and actor. Revue belge de philologie et d'histoire, t. 25, fasc. 3-4, pp. 485-508.

Williams, M. E. (1992) "A play is not so ydle a thing": The dramatic output and the theatre-craft of Nathan Field: A thesis submitted to the Faculty of Arts of the University of Birmingham for the degree of Doctor of Philosophy. Shakespeare Institute, University of Birmingham, May. [12], 454 p.

Williams, M. E. (2004) Field, Nathan (bap. 1587, d. 1619/20), actor and playwright. Oxford Dictionary of National Biography [online] Available at: https://www.oxforddnb.com/view/10.1093/ref:odnb/9780198614128.001.0001/odn b-9780198614128-e-9391 [archived in WaybackMachine] (accessed 22.11.2019). DOI: $10.1093 /$ ref:odnb/9391

Submission date: 15.12.2019.

Шипулина (Колесник) Виктория Андреевна - магистрант филологического факультета Православного Свято-Тихоновского гуманитарного университета. Адрес: 109651, Россия, г. Москва, ул. Иловайская, д. 9, корп. 2. Эл. адрес: Vika.kolesnik.1996@mail.ru 
Shipulina (Kolesnik) Viktoria Andreyevna, Master's Student, Faculty of Philology, St. Tikhon's Orthodox University. Postal address: Bldg. 2, 9 Ilovaiskaya St., 109651 Moscow, Russian Federation. E-mail: Vika.kolesnik.1996@mail.ru

Макаров Владимир Сергеевич - кандидат филологических наук, доцент кафедры германской филологии филологического факультета Православного Свято-Тихоновского гуманитарного университета. Адрес: 109651, Россия, г. Москва, ул. Иловайская, д. 9, корп. 2. Тел.: +7 (495) 646-71-38. Эл. адрес: mail@vmakarov.name

Makarov Vladimir Sergeyevich, Candidate of Philology, Associate Professor, Department of Germanic Philology, Faculty of Philology, St. Tikhon's Orthodox University. Postal address: Bldg. 2, 9 Ilovaiskaya St., 109651 Moscow, Russian Federation. Tel.: +7 (495) 646-71-38. E-mail: mail@vmakarov.name

\section{Для циитирования:}

Шипулина В. А., Макаров В. С. Письмо Натана Филда к Томасу Саттону в контексте театральной полемики раннестюартовской Англии [Электронный ресурс] // Горизонты гуманитарного знания. 2019. № 6. С. 99-115. URL: http://journals.mosgu.ru/ggz/article/view/1139 (дата обращения: дд.мм. гггг). DOI: 10.17805/ggz.2019.6.6 